DOI https://doi.org/10.30525/978-9934-26-110-7-54

\title{
ДОСЛІДЖЕННЯ ТОПОНІМІВ ХАРКІВЩИНИ У ВІТЧИЗНЯНІЙ ОНОМАСТИЦІ
}

\author{
Підгородецька І. Ю.
}

кандидат філологічних наук, доцент, доиент кафедри мовних дисциплін

Харківський національний аграрний університет імені В. В. Докучаєва

Тихоненко О. В.

кандидат філологічних наук, доцент, доцент кафедри мовних дисииплін

Харківський національний аграрний університет імені В. В. Докучаєва м. Харків, Україна

Сучасна ономастика - це міждисциплінарна наукова дисципліна, предметом дослідження якої $\epsilon$ етимологія, трансформації, функціонування власних назв - онімів, що є джерелом історичної, географічної, етнографічної, соціологічної, літературознавчої інформації тощо.

В Україні за часів незалежності інтерес до топоніміки виявляється переважно на регіональному рівні. На основі вивчення проблематики розвитку окремих міст України з'являються нові розвідки з теоретичної та прикладної урбаноніміки як розділу топоніміки, у якому досліджують проблеми внутрішньоміських найменувань.

Зацікавленість сучасних науковців питаннями регіоналізму й регіональних ідентичностей сприяла появі низки публікацій, у яких поряд із особливостями ментальності, культури, економіки розглядають символічний простір міст. Дослідження генези і трансформації урбанонімів дають змогу уточнити, деталізувати минуле, відкривають додаткові можливості для вивчення політичних, економічних, соціальних, культурних процесів у діахронному розрізі.

Протягом кількох останніх десятиліть урбаноніми Харкова досліджують переважно в культурно-історичному, ідеологічному, етимологічному аспектах, аналізуючи витоки формування місцевої топонімії; перші найменування й перейменування вулиць, провулків, площ тощо; особливості топонімічної політики Харківської міської думи наприкінці XIX ст.; розвиток адресної урбанонімії в синхронії й діахронії; топоніми, пов'язані 3 університетом імені В.Н. Каразіна (О. Довженко, М. Дьяченко, С. Журавльова, М. Тахтаулова, О. Хорошковатий). Географи В. Машкіна, Є. Рубашенко аналізують просторово-часові зміни урбанонімічного простору міста. Окремі відомості про топонімічне й архі- 
тектурне оформлення вулиць, історії про мешканців та установи Харкова містяться в роботах численних авторів, переважно харків'ян, серед яких архітектор О. Лейбфрейд, журналісти I. Можейко і К. Кеворкян, краєзнавці М. Красіков, І. Саратов, С. Плотичер і Л. Мачулін.

За останнє десятиріччя наукова література про Харків та Харківщину поповнилася працями мовознавців, присвяченими топонімії міста, у яких харківські урбаноніми аналізують не тільки в культурно-історичному аспекті, а й розглядають у річищі мовознавчих проблем. Учені розглядають урбаноніми Харкова й процеси створення неофіційної й офіційної номінації, лінгвістичну специфіку назв вулиць та інших об'єктів міста, зокрема, здійснюють лінгвістичний аналіз найменувань антропонімного походження, вивчають їхню словотвірну специфіку, а також суспільні та культурні чинники впливу на функціонування урбанонімів [5]. Науковці досліджують назви вулиць та інших внутрішньоміських об'єктів Харкова, що завдяки закону про декомунізацію набули своїх попередніх, дореволюційних назв [1]. На матеріалі годонімів дослідники порушують проблему формування мовного ландшафту Харкова впродовж історичного буття міста в контексті соціальних і політичних змін [2]; виявляють особливості мотивації і функціонування урбанонімів із сакральною семантикою в онімному просторі Харкова [4]; аналізують віконіми (назви лінійних сільських об'єктів) Харківського регіону в номінативному аспекті [3].

Отже, проблемні питання топонімікону Харківщини привертають увагу спеціалістів різних наукових галузей, що дає змогу комплексно дослідити онімний простір названого регіону. У добу незалежності зусилля вітчизняних ономастів спрямовані насамперед на відновлення історичної пам'яті, повернення втрачених назв на топонімічну мапу України, зокрема Харкова й Харківської області. Постійне вивчення топонімів Харківщини зумовлене також динамічним розвитком області, збільшенням іï території, появою нових імен на мапі, а також необхідністю всебічного опису й вивчення історико-культурних, лінгвокультурних і топонімічних традицій, способів формування топонімікону харківського регіону.

Подальше дослідження вбачаємо у визначенні лінгвокультурологічних характеристик топонімікону Харківщини, описі його структурно-семантичних моделей. Поглиблене вивчення допоможе осягнути складники ономастичної картини світу, усвідомити ономастичну творчість як частину загальнокультурного процесу.

\section{Література:}

1. Гарбар М. А. Повернені із забуття: топоніми сучасних вулиць Харкова Вісник Харківського національного університету імені В. Н. Каразіна. Сер. «Історія Украӥни. Украӥнознавство: історичні та філософські науки». Харків, 2018. Вип. 26. С. 125-128. 
2. Герман Л. В., Підгородецька І. Ю., Тихоненко О. В. Основні етапи становлення мовного ландшафту Харкова на тлі соціально-політичних змін. Актуальні питання гуманітарних наук: міжвуз. зб. наук. пр. молодих учених Дрогобицького державного педагогічного університету ім. І. Франка. Дрогобич, 2020. Вип. 28. Т. 1. С. 46-54.

3. Підгородецька І. Ю., Тихоненко О. В. Віконімія Харківщини: номінативний аспект. Мова $i$ культура. 2020. Вип.22. T.V (200). C. $274-282$.

4. Підгородецька І. Ю., Тихоненко О.В.Сакральні назви як компонент онімного простору Харкова: історія і сьогодення. Theoretical and practical aspects of the development of the European Research Area: Monograph / edited by authors. 2nd ed. Riga, Latvia, 2020. P. 303-329.

5. Удовенко Л. О. Урбаноніми антропонімного походження на мапі сучасного Харкова. Вісник Харківського начіонального університету імені В. Н. Каразіна. Сер. «Історія України. Украӥнознавство: історичні та філософські науки». Харків, 2020. Вип. 30. С. 94-107.

DOI https://doi.org/10.30525/978-9934-26-110-7-55

\title{
ЕТНОЛІНГВІСТИЧНІ АСПЕКТИ У ФОРМУВАННІ МОВНОКОМУНІКАТИВНОЇ КОМПЕТЕНЦЇ̈ МАЙБУТНІХ ПЕДАГОГІВ
}

\author{
Стрельбіцька О. О. \\ кандидат філологічних наук, \\ старший викладач кафедри філологіі \\ Комунальний заклад вищої освіти «Луцьький педагогічний коледж» \\ Волинської обласної ради \\ Подолюк С. М. \\ кандидат філологічних наук, \\ викладач-методист кафедри філології \\ Комунальний заклад вищої освіти «Луцький педагогічний коледж» \\ Волинської обласної ради \\ м. Луиьк, Україна
}

Формування національно свідомої, духовно багатої мовної особистості - на сьогодні чи не найважливіше питання національної стратегії розвитку держави загалом, та освітньої реформи зокрема. Аналіз чинних концепцій мовної освіти в Україні свідчить про 